\title{
Investigation into the Question of Complex Processing of Bauxites of the Srednetimanskoe Deposit
}

\author{
I. V. Loginova*, A. V. Kyrchikov**, V. A. Lebedev***, and S. F. Ordon**** \\ Ural Federal University, ul. Mira 19, Yekaterinburg, 620002 Russia \\ *e-mail: loginova_irina@mail.ru \\ **e-mail:akirchikov@yandex.ru \\ ***e-mail:mlm@mail.ustu.ru \\ ****e-mail: ordon.sergey@mail.ru
}

\begin{abstract}
A new technology of processing raw materials with the use of active alkali is suggested for bauxites of the Srednetimanskoe deposit; bauxite is opened at $300^{\circ} \mathrm{C}$ for $1 \mathrm{~h}$. This technology makes it possible to increase the recovery of alumina to $94-98 \%$ and obtain red slimes and zeolite enriched with iron (58\%) and titanium (4.8\%); the environmental problem of storing red slimes is resolved. The blast-furnace smelting of such slimes makes it possible to obtain naturally doped cast iron and slag enriched with titanium and rare earth metals. When purifying (desiliconizing) the aluminate solution, a valuable product—-sodium aluminum silicate hydrate of the zeolite type — is incidentally obtained.
\end{abstract}

Keywords: bauxite, alkali-aluminate solution, metastable state, iron ore, red slime, blast-furnace smelting, naturally doped cast iron, zeolite, complex processing

DOI: $10.3103 / \mathrm{S} 1067821213020089$

From the moment the Bayer method appeared in alumina technology, the notion of the quality of the bauxite raw material has been a constant. The most basic and constantly accompanying impurity of the latter is silica, which almost completely dissolves during the production process, transferring into sodium silicate. In turn, favorable conditions for the interaction of sodium silicate with components of the alkalialuminate solution appear with the formation of lowsoluble sodium aluminum silicate hydrate ( $\mathrm{SASH})$ of the following chemical composition: $\mathrm{Na}_{2} \mathrm{O} \cdot \mathrm{Al}_{2} \mathrm{O}_{3}$. $n \mathrm{SiO}_{2} \cdot 2 \mathrm{H}_{2} \mathrm{O}(n=1.75-2.00)$ at elevated temperatures and the prolonged duration of some processes [1]. Several types of SASH are revealed in alumina industry: nosean, sodalite, cancrinite, zeolite, etc. They differ from each other by the incorporation of various ions in the aluminate solution into the crystal lattice skeleton and by the degree of saturation by silica [2]. The main negative consequence of the formation of these compounds is the loss of valuable components of the alkali-aluminate solution with silica. Therefore, it is recommended to process the bauxites with a silicon module of $\geq 6-7$ units using the Bayer method. The sintering method is more reasonable for bauxites with smaller silicon modules.

Currently, Ural alumina plants operate using a mixture of SUBR and STBR bauxites. In the future they will process only STBR bauxites.

Bauxites of the Srednetimanskoe deposit (the STBR bauxite mine) are ore of medium quality; their silicon module is mainly 6-7 units. In connection with this, it is desirable to investigate the behavior of silica in alkali-aluminate solutions.

STBR bauxites belong to the boehmite-chamosite-hematite type with a small diaspore impurity. They are high-ferrous, sulfur-free, and low-carbonate. In contrast to North Ural bauxites (SUBR), where the main alumina-containing mineral is diaspore, it is boehmite in STBR bauxites, which is confirmed by the spectral analysis data (Fig. 1). Boehmite is a more chemically active form of aluminum hydroxide when compared with the diaspore of SUBR bauxites.

Silica-containing minerals of the STBR bauxite are presented by chamosite and kaolinite. A higher chamosite content is characteristic of low-module bauxites. The content of these minerals considerably varies, which is a distinctive feature of bauxites of the Srednetimanskoe group. The main iron-containing mineral in STBR bauxites is hematite.

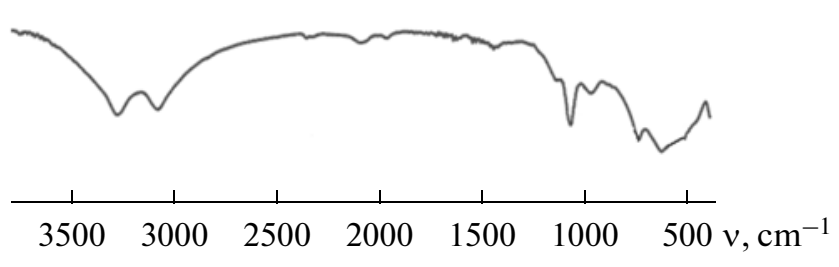

Fig. 1. IR spectrum of the starting sample of the STBR bauxite. 


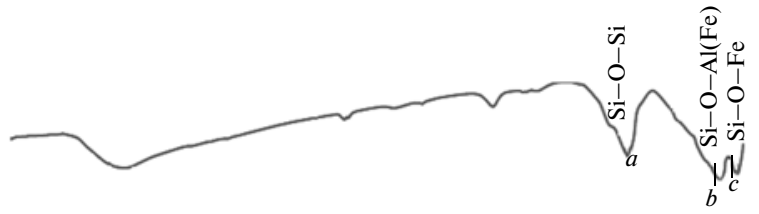

$\begin{array}{lllllll}3500 & 3000 & 2500 & 2000 & 1500 & 1000 & 500 \mathrm{v}, \mathrm{cm}^{-1}\end{array}$

Fig. 2. IR spectrum of the plant red slime after autoclave leaching of the STBR bauxite.

Absorption spectra of boehmite (OH corresponds to $v=3000-3500 \mathrm{~cm}^{-1}$ ) and weak spectra of kaolinite and chamosite are clearly seen in the IR spectrogram of STBR bauxite. Thus, the larger part of active aluminum in bauxite is contained in the form of boehmite.

The results of the spectral analysis of red slimes after the autoclave leaching of STBR bauxites show that $\mathrm{Al}_{2} \mathrm{O}_{3}$-containing mineral chamosite does not decompose completely during leaching; the characteristic absorption bands of chamosite are (a) 990, (b) 560 , and (c) $460 \mathrm{~cm}^{-1}$ (Fig. 2).

The behavior of chamosite during the autoclave leaching of bauxites is of certain interest for the production process. This material is a layered aluminum silicate. Ferrous chlorite is often implied under the term "chamosite." The chemical composition of chamosites is very unstable. Chamosites with the prevalence of divalent and trivalent iron $\left(\mathrm{Fe}^{2+}, \mathrm{Fe}^{3+}\right)$ are met. The limits of the content of basic oxides are varied in them: $\mathrm{SiO}_{2}=18-33, \mathrm{Al}_{2} \mathrm{O}_{3}=20-30, \mathrm{Fe}_{2} \mathrm{O}_{3}=1-18, \mathrm{FeO}=$ $2-39, \mathrm{MgO}=0.6-6.5$, and $\mathrm{H}_{2} \mathrm{O}=7-11 \%$.

It was established experimentally that the chamosite solubility in aluminate solutions of the Bayer process depends on its chemical and mineralogical compositions [2]. Particularly, deeply oxidized chamosite containing $<1 \% \mathrm{FeO}$ dissolves by $96 \%$ already at $95^{\circ} \mathrm{C}$ for $4 \mathrm{~h}$, while the low-oxidized chamosite, which includes $\sim 11.5 \% \mathrm{FeO}$, dissolves by $25-35 \%$ under the same conditions. Chamosite interacts with $\mathrm{NaOH}$ as follows:

$$
\begin{gathered}
2\left(4 \mathrm{FeO} \cdot \mathrm{Al}_{2} \mathrm{O}_{3} \cdot 3 \mathrm{SiO}_{2} \cdot 4 \mathrm{H}_{2} \mathrm{O}\right)+4 \mathrm{NaOH} \\
+2 \mathrm{NaAlO}_{2}+3 x \mathrm{H}_{2} \mathrm{O} \\
=3\left(\mathrm{Na}_{2} \mathrm{O} \cdot \mathrm{Al}_{2} \mathrm{O}_{3} \cdot 3 \mathrm{SiO}_{2} \cdot x \mathrm{H}_{2} \mathrm{O}\right)+2 \mathrm{Fe}_{3} \mathrm{O}_{4} \\
+2 \mathrm{FeO}+8 \mathrm{H}_{2} \mathrm{O}+2 \mathrm{H}_{2} \uparrow .
\end{gathered}
$$

This chemical reaction can be a reason for the pressure increase and appearance of divalent iron in solutions [3]. It was established that, when processing Srednetimanskoe bauxites at Ural aluminum plants, the blowing frequency of formed gases in autoclave batteries increased abruptly, which also confirms the version of decomposition of chamosite during leaching. It should be noted that the evolution of hydrogen during the passage of this reaction can be explosively dangerous. Therefore, certain cautions should be followed when operating with this type of bauxite.
We studied a new direction in processing bauxites of the Srednetimanskoe deposit, which makes it possible to considerably increase the recovery of $\mathrm{Al}_{2} \mathrm{O}_{3}$ from the bauxite raw material and lower the losses of alkali and aluminum with red slime. We also attempted to resolve the problem of the complex processing of the bauxite raw materials and processing red slimes of alumina production due to the acquisition of high-ferrous red slime, which can be further used as the raw material for obtaining cast iron and high-titanium slags with an increased content of rare earth elements [4]. The application of this technology will make it possible to completely liquidate slime storages in alumina production and improve environmental safety at the enterprise. Laboratory investigations were performed with the Timan bauxite of the following chemical composition, \%:

$\begin{array}{lrlr}\mathrm{Al}_{2} \mathrm{O}_{3} & 49.64 & \mathrm{CO}_{2} & 0.17 \\ \mathrm{SiO}_{2} & 6.86 & \mathrm{~S} & 0.05 \\ \mathrm{Fe}_{2} \mathrm{O}_{3} & 27.23 & \mathrm{LDC} & 10.81 \\ \mathrm{FeO} & 1.62 & \mu_{\mathrm{Si}} & 7.2 \\ \mathrm{TiO}_{2} & 3.00 & & \end{array}$

In experiments we used the plant recycled solution with the chemical composition $\mathrm{Al}_{2} \mathrm{O}_{3}-150, \mathrm{Na}_{2} \mathrm{O}_{\text {tot }}$ 310 , and $\mathrm{Na}_{2} \mathrm{O}_{\text {caust }} 290 \mathrm{~g} / \mathrm{L}$.

Bauxite was opened by charge processing with the recycled alkali-aluminate solution at atmospheric pressure. The pulp was heated to the complete evaporation of water with the subsequent holding of the mixture at $t=300^{\circ} \mathrm{C}$ for $1 \mathrm{~h}$ (it is planned to further use evaporated water for cake leaching). As a result, the active caustic alkali of the recycled solution actively interacts with boehmite and iron-containing bauxite components with the formation of sodium aluminate and ferrite. Sodium silicate is also obtained in this case. Upon heating, solid substances interact with each other (solid-phase transformations). The melting point of each reaction product is very high, and sintering reactions proceed at lower temperatures in this case and correspond to the Tamman rule: "Cation exchange in solid proceeds with the measured rate after the temperature reaches values corresponding to $2 / 3$ of the melting point of the substance." The melting point of alkali corresponds to $323^{\circ} \mathrm{C}$; therefore, solid-phase reactions of the formation of sodium aluminate and ferrite occur at lower temperatures.

The sample was leached with water at $t=60-70^{\circ} \mathrm{C}$ with the transfer of useful components into the solution. At this temperature and the caustic module of the solution of 1.6-1.8 units, we obtained an alkali-aluminate solution of the following chemical composition: $\mathrm{Al}_{2} \mathrm{O}_{3}-130-150$ and $\mathrm{Na}_{2} \mathrm{O}=130-150 \mathrm{~g} / \mathrm{L}$ (the data on bauxite processing are presented in Table 1).

The explanation of these positive results is involved in more detailed consideration and an investigation into the behavior of silica in low-module alkali-aluminate solutions obtained by Lileev [5] and investigated by us in various production conditions. 


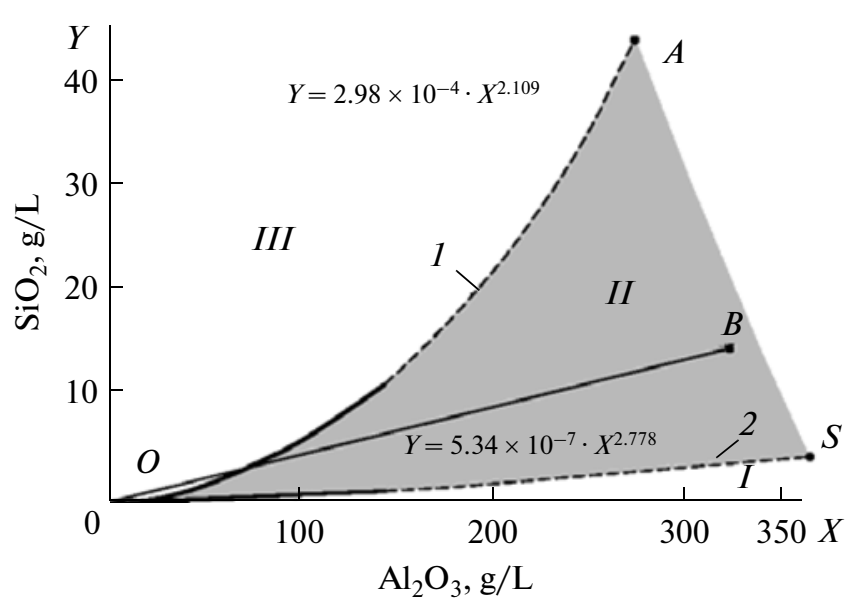

Fig. 3. Variation in the limiting (1) metastable and (2) equilibrium $\mathrm{SiO}_{2}$ concentration relative to $\mathrm{SASH}$ in aluminate solutions at $t=70^{\circ} \mathrm{C}$. Solid lines correspond to the Lileev data [5] and dashed lines correspond to the approximated data [6].

Three state regions of silica were clearly separated at $T=70^{\circ} \mathrm{C}$ (Fig. 3).

Region $I I$, which is restricted by the equilibrium state line of silica $(O S)$ and by the limiting supersaturation line $(O A)$ in the phase diagram, is a metastable region. The solution can be situated there in the metastable equilibrium state holding silica inside it. Region $I I I$ is labile and absolutely unstable, and the situation in it leads to spontaneous SASH crystallization. Further, we investigated the behavior of silica under the same conditions but only in the region of increased alumina concentrations in the solution. Due to averaging and approximating our experimental data, we succeeded in deriving the limitation equations for these regions (Fig. 3).

Extrapolating the experimental data on the behavior of silica in concentrated aluminate solutions, we found the mathematically processed results of its behavior in the solution and clearly isolated the region of the metastable state of silica [6].

We derived the silica content equations restricting these regions. The regularity of its holding in a metastable region was also confirmed for solutions with a high alumina concentration. It was also shown that, when diluting these concentrated solutions to generally acceptable concentrations of the aluminate solution, silica remains in a metastable region (curve $O B$ in Fig. 3) [6], which makes it possible further separate red slime from the aluminate solution.

We meet extremely high silica concentrations in aluminate solutions when leaching the ore and cake. The extremely low silica content (curve $O S$ in Fig. 3, the region of the equilibrium state of silica) finds its application upon the desiliconizing of aluminate solutions through SASH. The region above curve $O A$ is the region of the labile state of silica, where it cannot be practically held by the solution and isolated from it. Sodium silicate

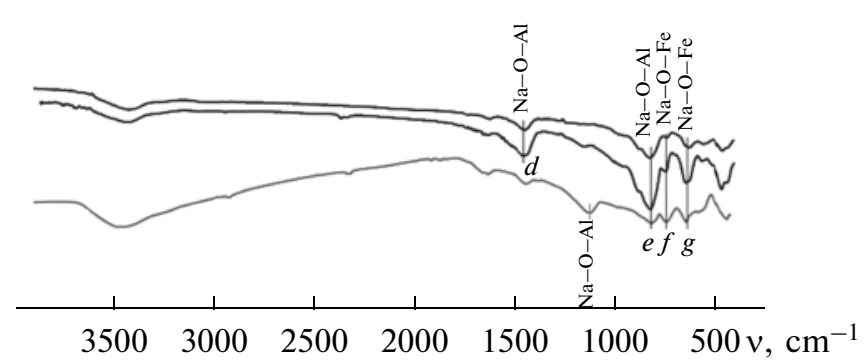

Fig. 4. IR spectra of cakes. (1) Cake with alkali excess, (2) cake with the recycled solution, and (3) plant cake (UAZ).

can be held in the aluminate solution in metastable region $I I$ (Fig. 3) without passing secondary losses in the SASH form. Point $B$, which is shown in Fig. 3 in the metastable equilibrium region, characterizes the maximal transfer of silica from the bauxite charge upon its complete decomposition [6]. It is clearly seen that, when diluting this solution, silica remains in the solution in a metastable region. Such a method makes it possible to obtain alkali-free high-ferrous slimes.

The aluminate solution was further desiliconized with the acquisition of zeolite-type SASH, which can further be a high-cost commercial product and can be used as a sorbent to purify radioactive waste waters. Artificially synthesized zeolites (permutites) find wide application in water-purifying devices such as adsorbents, ion exchangers, and molecular sieves; they are used as electron donors and acceptors. In addition, zeolites have found wide application as catalysts of many ion-exchange processes of petrochemistry and oil processing, as well as heterogeneous catalysts.

Desiliconizing the aluminate solution with an increased silica content can be performed similarly to fulfilling this operation now at UAZ in the sintering branch in the presence of a seed by means of stirring this solution in stirrers for $4-6 \mathrm{~h}$. This operation leaves the solution from the metastable state, and SASH starts to be isolated from it.

The recovery of alumina into the solution by the suggested technology reaches 95.6-98.0\% (its theoretical recovery by the Bayer method from this raw material is $\sim 86.2 \%$ ).

The data of the spectral analysis show (Fig. 4) that sodium aluminate and ferrite $\left(\mathrm{Na}_{2} \mathrm{O} \cdot \mathrm{Al}_{2} \mathrm{O}_{3}: d=1460\right.$,

Table 1. Results of processing the bauxite by a certain volume of the recycled solution

\begin{tabular}{c|c|c|c|c}
\hline $\begin{array}{c}\text { Experi- } \\
\text { ment no. }\end{array}$ & $\begin{array}{c}\text { Baux- } \\
\text { ite, g }\end{array}$ & $\begin{array}{c}\text { Recycled } \\
\text { solution, } \\
\text { mL }\end{array}$ & $\begin{array}{c}\text { Recovery } \\
\text { of alumina into } \\
\text { the solution, \% }\end{array}$ & $\begin{array}{c}\mathrm{Fe}_{2} \mathrm{O}_{3} \\
\text { content in } \\
\text { red slime, \% }\end{array}$ \\
\hline 1 & 10 & 25 & 98.0 & 83.0 \\
2 & 10 & 20 & 95.6 & 80.0 \\
3 & 10 & 15 & 75.5 & 55.4 \\
4 & 10 & 10 & 52.3 & 42.1 \\
5 & 10 & 5 & 25.4 & 39.0 \\
\hline
\end{tabular}



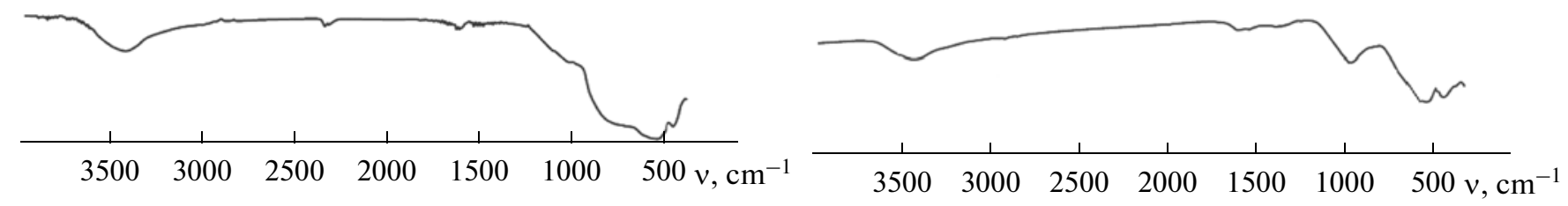

Fig. 5. Cake with a lack of alkali.

Fig. 6. IR spectrum of red slime obtained in laboratory.

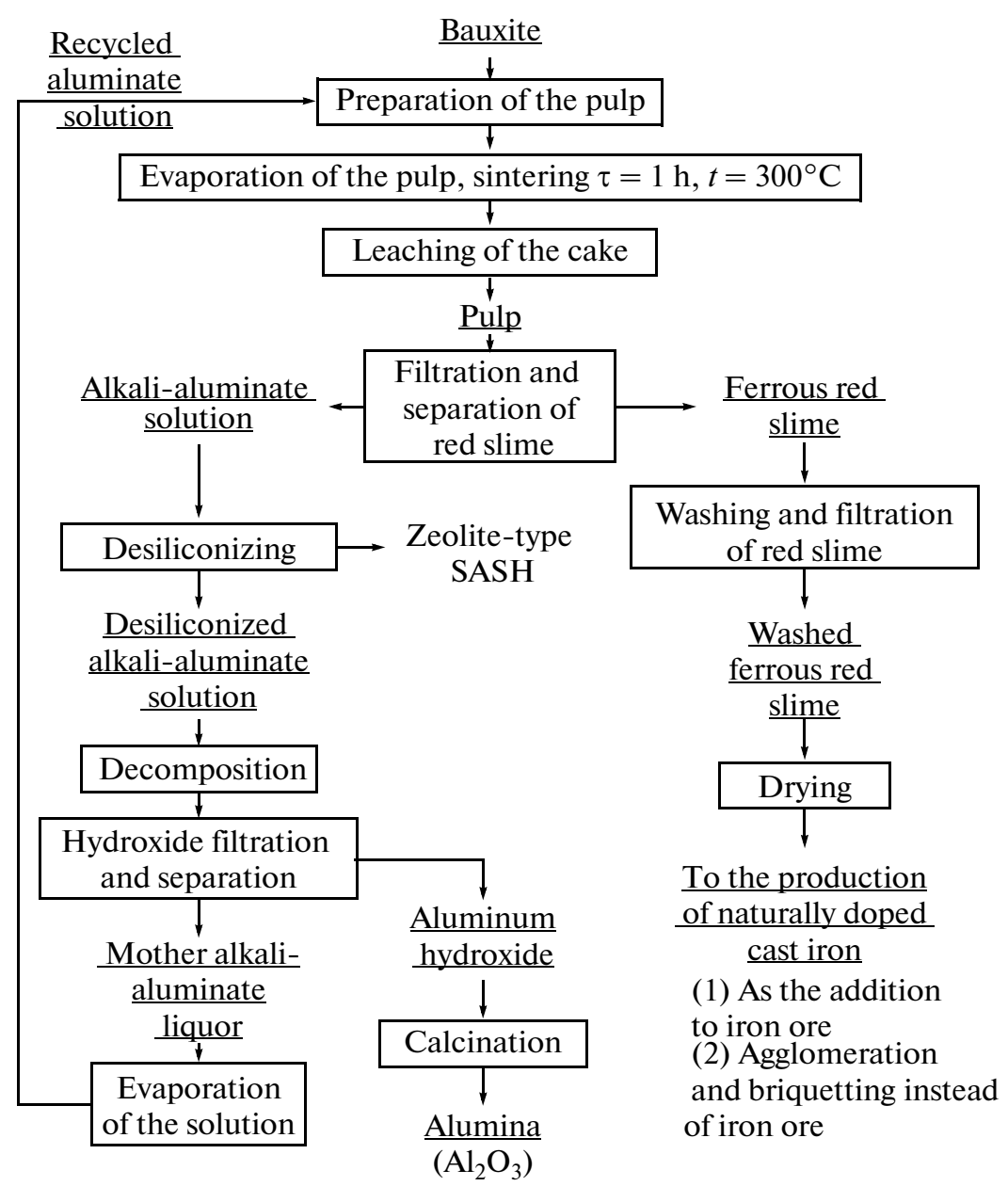

Fig. 7. Flow chart of complex processing the bauxites (a new technology).

$e=816 \mathrm{~cm}^{-1} ; \mathrm{Na}_{2} \mathrm{O} \cdot \mathrm{Fe}_{2} \mathrm{O}_{3}: f=730, g=640 \mathrm{~cm}^{-1}$ ) are present in the cake obtained during sintering with the recycled solution. For comparison, the IR spectrum of the factory cake from UAZ is presented in Fig. 4.

The lack of caustic alkali during sintering leads to the absence of sodium aluminate and ferrite in the cake (Fig. 5).

Absorption bands of chamosite are not pronounced in the IR spectrum of red slime obtained in the experiment (Fig. 6). It is mainly presented by hematite and titanium oxide.

Results of the chemical analyses show that the slime is enriched by $\mathrm{Fe}_{2} \mathrm{O}_{3}$ and $\mathrm{TiO}_{2}$. Averaged results of chemical analyses of red slimes are presented in Table 2.

These slimes substantially differ from existing slimes of Ural plants. They are characterized by a high iron content and low alkali and aluminum contents. In regards to the iron content, these slimes approach rich iron ores (the Fe content $>50 \%$ ). It is supposed to further use this slime as a raw material to produce cast iron in iron metallurgy.

We investigated smelting of the slime obtained according to a new technology jointly with the Institute of Metallurgy, Ural Branch, Russian Academy of 
Table 2. Chemical composition of slimes

\begin{tabular}{l|c|c|c|c|c|c}
\hline \multicolumn{1}{c|}{ Slimes } & $\mathrm{Fe} / \mathrm{Fe}_{2} \mathrm{O}_{3}$ & $\mathrm{Ti} / \mathrm{TiO}_{2}$ & $\mathrm{Al} / \mathrm{Al}_{2} \mathrm{O}_{3}$ & $\mathrm{Si} / \mathrm{SiO}_{2}$ & $\mathrm{Ca} / \mathrm{CaO}$ & $\mathrm{Na} / \mathrm{Na}{ }_{2} \mathrm{O}$ \\
\hline $\begin{array}{l}\text { According to the suggested } \\
\text { technology }\end{array}$ & $58.7 / 83.9$ & $4.84 / 8.0$ & $4.23 / 7.9$ & $2.57 / 5.5$ & $0.30 / 0.4$ & $0.19 / 0.3$ \\
\begin{tabular}{l} 
Plant (averaged data) \\
\hline
\end{tabular} & $31.26 / 44.7$ & $1.80 / 3.0$ & $7.94 / 15.0$ & $3.79 / 8.1$ & $7.86 / 11.0$ & $2.25 / 3.0$ \\
\hline
\end{tabular}

Sciences (Yekaterinburg). In order to determine the composition of casts, a chemical analysis of samples and slags was performed. The content of elements in the cast iron was V 0.12, Cr 0.046, Mn 0.93, Co, 0.048, and $\mathrm{W} 0.6 \%$.

During melting, valuable doping components from the slime transfer into the composition of the cast and so-called naturally doped cast iron is obtained. The slag obtained after smelting is enriched with titanium oxides and rare earth elements.

A flow chart of the proposed technology is presented in Fig. 7.

\section{CONCLUSIONS}

(i) According to the results of our investigations, the technology of processing bauxites of the Srednetimanskoe deposit, making it possible to considerably increase the recovery of $\mathrm{Al}_{2} \mathrm{O}_{3}$ from the bauxite raw materials, is suggested.

(ii) It turned out to be possible to decrease the losses of alkali and aluminum with red slime by holding silica in the solution with its subsequent separate precipitation.

(iii) The solution to the serious environmental problem of storing red slimes of alumina production is suggested. (iv) The possibility of the complex processing of bauxite with the acquisition of alumina, high-ferrous red slime, and zeolite-type SASH is suggested.

\section{REFERENCES}

1. Lainer, A.I., Eremin, N.I., Lainer, Yu.A., and Pevzner, I.Z., Proizvodstvo glinozema (Alumina Production), Moscow: Metallurgiya, 1978.

2. Ni, L.P. and Khalyapina, O.B., Fiziko-khimicheskie svoistva syr'ya $i$ produktov glinozemnogo proizvodstva (Physicochemical Properties of Raw Materials and Products of Alumina Production), Alma-Ata: Nauka, 1978.

3. Loginova, I.V. and Kyrchikov, A.V., Proizvodstvo glinozema (Alumina Production), Yekaterinburg: UGTU-UPI, 2010.

4. Loginova, I.V., Loginov, Yu.N., Ordon, S.F., and Lebedev, V.A., RF Patent no. 2232716, 2004.

5. Spravochnik metallurga po tsvetnym metallam. Proizvodstvo glinozema (Metallurg Handbook on Nonferrous Metals. Alumina Production), Moscow: Metallurgiya, 1970.

6. Loginova, I.V., Koryukov, V.N., Novozhenov, V.M., and Kropotin, V.E., Izv. Vyssh. Uchebn. Zaved., Tsvetn. Metall., 1986, no. 5, p. 39. 